\title{
New Disease Reports \\ First report of natural infection of Agapanthus sp. by Eggplant mottled dwarf virus (EMDV)
}

\author{
Y. Zhai ${ }^{1}$, R. Miglino ${ }^{2}$, R. Sorrentino ${ }^{3}$, V. Masenga ${ }^{4}$, D. Alioto ${ }^{3}$ and H.R. Pappu $^{1 *}$ \\ ${ }^{1}$ Department of Plant Pathology, Washington State University, Pullman, WA 99164, USA ; ${ }^{2}$ BKD, Lisse, The Netherlands; ${ }^{3}$ \\ Department of Agriculture, University of Naples Federico II, Italy; ${ }^{4}$ IVV, Institute of Plant Virology, CNR, Torino, Italy
}

*E-mail: hrp@wsu.edu

Received: 09 Feb 2014. Published: 17 May 2014. Keywords: ELISA, RT-PCR, RNA-directed RNA polymerase

\begin{abstract}
A survey to identify the presence of Eggplant mottled dwarf virus (EMDV) in cultivated and wild plants in Latium region, Italy, was conducted during September 2012. In the same area, potted plants of Agapanthus sp., with symptoms suggestive of virus infection (bright mosaic consisting of white and yellow rectangular/oval to linear patches and stripes, often confluent, on leaves, flower stalks and buds) were observed in a private garden of Minturno (Fig. 1). Symptoms included 'colour-breaking' and flower distortion. Electron microscopic examination of leaf-dip preparations, by applying negative staining with $2 \%$ uranyl acetate, and ultrathin sections of symptom-bearing leaves showed only the presence of bacilliform enveloped rhabdovirus-like particles in the cytoplasm of Agapanthus cells.
\end{abstract}

Symptomatic samples were further tested for the presence of EMDV using double antibody sandwich enzyme-linked immunosorbent assay (DASELISA), reverse transcription-polymerase chain reaction (RT-PCR) and mechanical inoculation of herbaceous test plants assays. When tested by DAS-ELISA using a commercial polyclonal antiserum, extracts of symptomatic leaves showed positive reaction for EMDV (genus Nucleorhabdovirus, family Rhabdoviridae). The virus was mechanically transmissible to Chenopodium quinoa, whereas repeated attempts to transmit the virus by sap inoculation to different test plants (Nicotiana benthamiana, N. glutinosa, N. rustica, N. tabacum cvs. Samsun and White Burley) failed.

Total RNA was extracted from $100 \mathrm{mg}$ of fresh Agapanthus plant tissue using the RNeasy Plant Kit (Qiagen GmbH, Germany). Amplification of a portion of the viral genome by RT-PCR was done with EMDV polymerase (P) gene specific primers (Rhab for: 5'-GGAGTGGGTAGTATTGGATCAGAA-3', Rhab rev: 5'-CTTGGAAAAGACAGGATGGC-3'). A distinct DNA fragment of about 1,028 base pairs (bp) in size was amplified. The PCR amplicon was directly sequenced in both directions. Sequence homology using BLAST analysis showed high nucleotide sequence identity with the $\mathrm{P}$ gene of EMDV (GenBank Accession No. AM922322). The RNA genome of the virus was partially characterised. Through primer-walking, a total of 6499 nucleotides (nt) of the 3' half of the viral genome was obtained as cDNA, cloned and sequenced. The assembled 6499 nt cDNA sequence (KF410949) had an open reading frame (from 518 to 6358) potentially coding for a 1946 amino acid (aa) protein, and the aa sequence of this putative RNA-directed RNA polymerase (RdRp) shared $97 \%$ identity with that of EMDV (Pappi et al., 2013), confirming the identity of the virus isolated from diseased Agapanthus as EMDV. To our knowledge, this is the first report of natural infection of Agapanthus by EMDV. EMDV continues to be an economically important viral pathogen of several crops in Europe (Miglino et al., 2013; Parrella et al., 2013) and this report of EMDV infection of an ornamental plant suggests its increasing host range and that infected Agapanthus might act as a potential reservoir for EMDV.

\section{References}

Miglino R, Sorrentino R, De Stradis A, Zoina A, Alioto D, 2013. Necrotic potato tubers infected by eggplant mottled dwarf virus in Italy. Journal of Plant Pathology 95, 619-621. http://dx.doi.org/10.4454/JPP.V95I3.006

Pappi PG, Dovas CI, Efthimiou KE, Maliogka VI, Katis NI, 2013. A novel strategy for the determination of a rhabdovirus genome and its application to sequencing of Eggplant mottled dwarf virus. Virus Genes 47, 105-113. http://dx.doi.org/10.1007/s11262-013-0911-5

Parrella G, De Stradis A, Greco B, Villanueva F, Fortes IM, Navas-Castillo J, 2013. First report of Eggplant mottled dwarf virus in China rose in southern Spain. Spanish Journal of Agricultural Research 11, 204-207. http://dx.doi.org/10.5424/sjar/2013111-3461

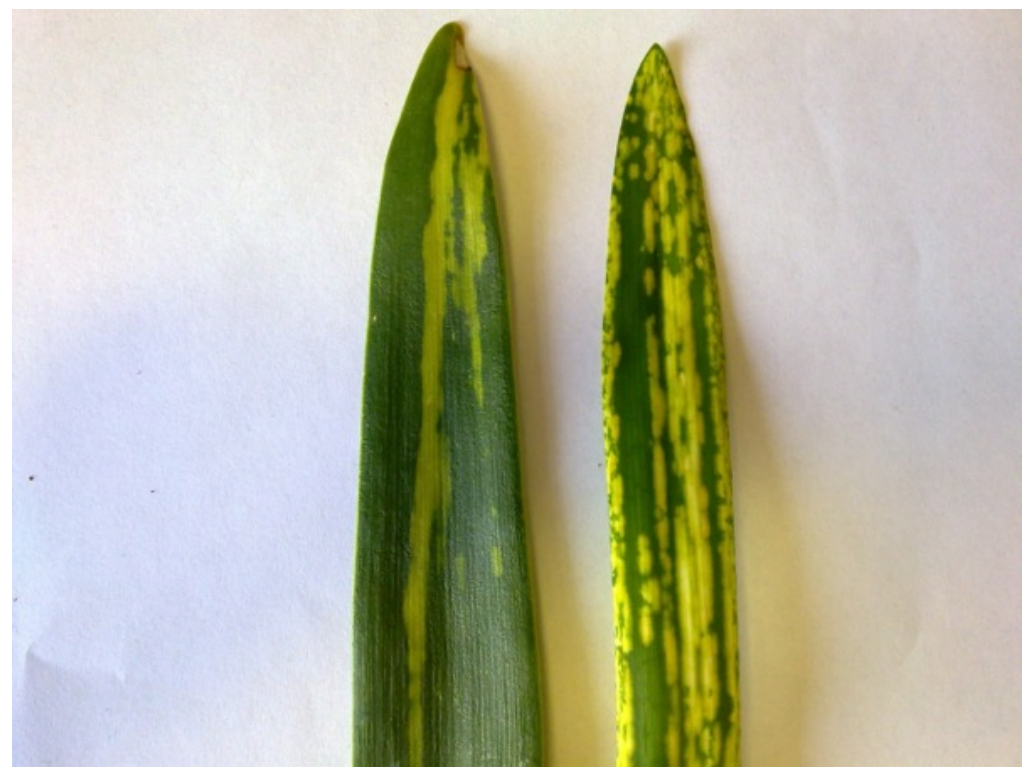

Figure 1

To cite this report: Zhai Y, Miglino R, Sorrentino R, Masenga V, Alioto D, Pappu HR, 2014. First report of natural infection of Agapanthus sp. by Eggplant mottled dwarf virus (EMDV). New Disease Reports 29, 20. http://dx.doi.org/10.5197/j.2044-0588.2014.029.020 